\title{
Recombinant interferon-gamma induces HLA-DR expression on human corneal epithelial and endothelial cells in vitro: a preliminary report
}

\author{
AHMED M ABU EL-ASRAR,' JOOST J VAN DEN OORD, ${ }^{2}$ \\ ALFONS BILLIAU, ${ }^{3}$ VALEER DESMET, ${ }^{2}$ MOHAMED H EMARAH, \\ AND LUC MISSOTTEN ${ }^{4}$
}

From the 'Department of Ophthalmology, Mansoura University Hospital, Egypt; ${ }^{2}$ Department of Pathology, Laboratory of Histo- and Cytochemistry, University of Leuven, Leuven, Belgium; ${ }^{3}$ Rega Institute for Medical Microbiology, University of Leuven, Belgium; and ${ }^{4}$ Department of Ophthalmology, University Hospital St Rafael, University of Leuven, Leuven, Belgium

SUMmARY The effect of interferon-gamma on the expression in situ of major histocompatibility complex (MHC) products in human corneas was studied in vitro. Incubation for four days with 5 or $50 \mathrm{mg} / \mathrm{l}$ of Escherichia coli-derived recombinant human interferon-gamma resulted in the appearance de novo of MHC class II or HLA-DR antigens on variable numbers of corneal epithelial cells as well as on corneal endothelium, whereas it had no effect on the expression of MHC class I or HLA-ABC antigens. These results may help to explain the mechanism underlying the expression of HLA-DR antigens on corneal and limbal epithelium in various inflammatory eye diseases.

Major histocompatibility complex (MHC) class II products or HLA-DR antigens are highly polymorphic cell surface glycoproteins involved in antigen presentation and initiation of $\mathrm{T}$ lymphocytedependent immune responses. HLA-DR antigens are predominantly expressed on immunocompetent cells such as B lymphocytes, activated T lymphocytes, macrophages, dendritic cells, and endothelial cells. ${ }^{1}$ In addition a variety of epithelial cell types are now known to express HLA-DR antigens constitutionally or following induction with lymphokines. ${ }^{2}$

In the normal human cornea HLA-DR antigens are expressed on occasional dendritic cells in the epithelium and stroma ${ }^{34}$ and on the endothelial cells lining the limbal blood vessels. ${ }^{5-7}$ Normal corneal epithelium and endothelium, as well as the majority of stromal cells, lack HLA-DR antigens.

We recently observed HLA-DR antigen expression on corneal epithelium in herpetic keratitis, ${ }^{8}$ on limbic epithelium in phlyctenular eye disease, ${ }^{9}$ and on conjunctival epithelium in trachomatous conjunc-

Correspondence to Professor Dr L Missotten, Department of Ophthalmology, University Hospital St Rafael, University of Leuven, Kapucijnenvoer 7, B-3000 Leuven, Belgium. tivitis.$^{10}$ In all these conditions variable numbers of T cells were found in the epithelial and stromal inflammatory infiltrate, suggesting that lymphokines liberated by these $T$ cells were responsible for the epithelial HLA-DR expression. The lymphokine, interferon-gamma, produced by activated $T$ cells has been shown to induce synthesis and expression of HLA-DR antigens in a variety of epithelial cells in vitro. ${ }^{211}$

In the present study we have investigated whether interferon-gamma can induce HLA-DR expression by the corneal and limbic epithelium in vitro.

\section{Materials and methods}

Eyes were obtained at necropsy within a few hours of death. The corneas used in this study were excised with a $3 \mathrm{~mm}$ scleral margin and divided into three parts. Each piece of cornea was placed in a separate bottle containing $10 \mathrm{ml}$ of organ culture medium. ${ }^{12}$ The first corneal part served as a control. To the culture medium of the second and third bottles human pure recombinant Escherichia coli-derived 587 


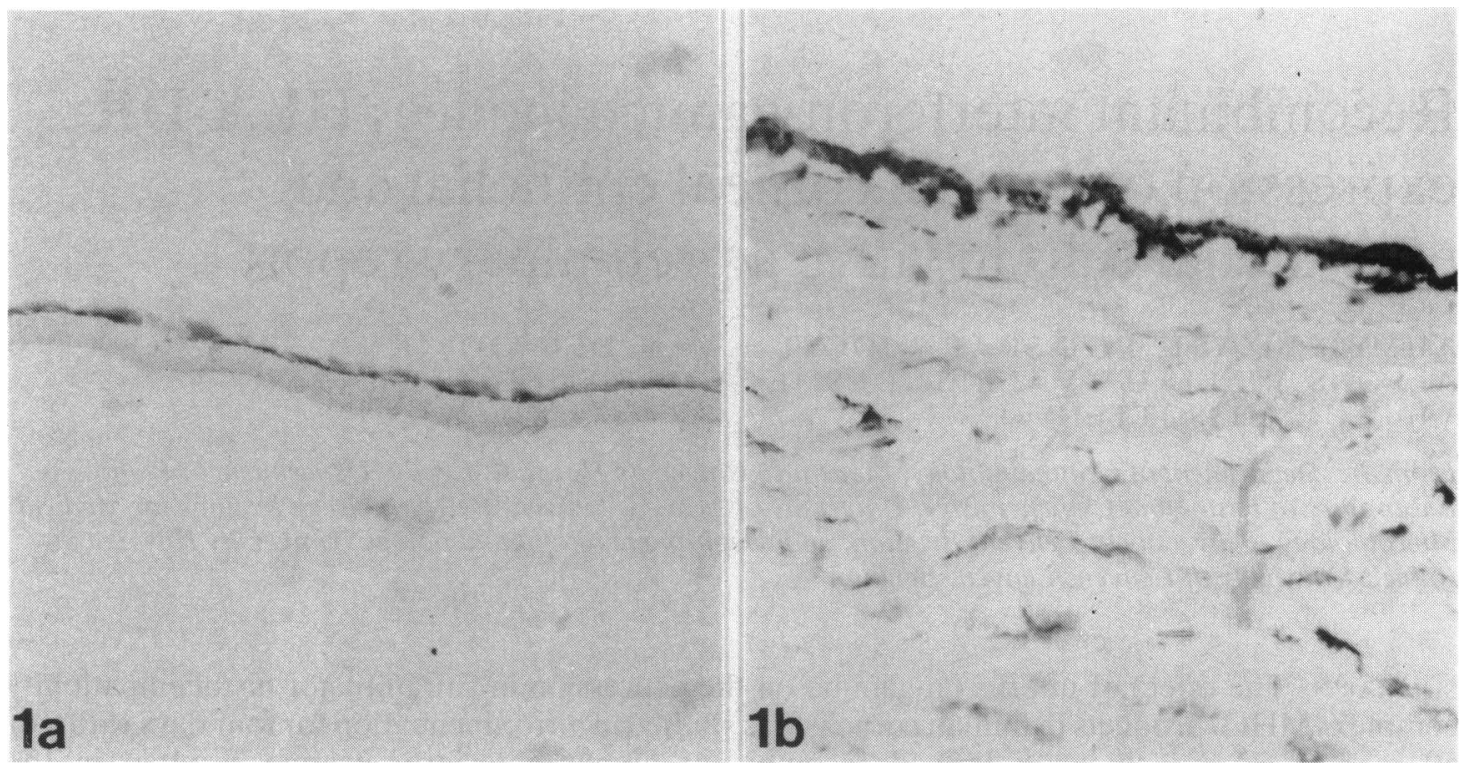

Fig. 1 Effect of interferon-gamma on HLA-DR expression by corneal endothelium. 1a. No endothelial reactivity is seen in the control specimen. 1b. Four days of incubation with $50 \mathrm{mg} / \mathrm{l}$ interferon-gamma reveals $H L A$-DR expression by corneal endothelium and by variable numbers of stromal cells.

$\mathrm{mg} / \mathrm{l}$ respectively. Recombinant interferon-gamma was kindly supplied by Dr W Wolf (Bioferon GmbH \& Co, Laupheim, West Germany). The three bottles were incubated at $37^{\circ} \mathrm{C}$ in $5 \% \mathrm{CO}_{2}$ for four days; subsequently the corneal pieces were snap frozen in isopentane cooled liquid nitrogen.

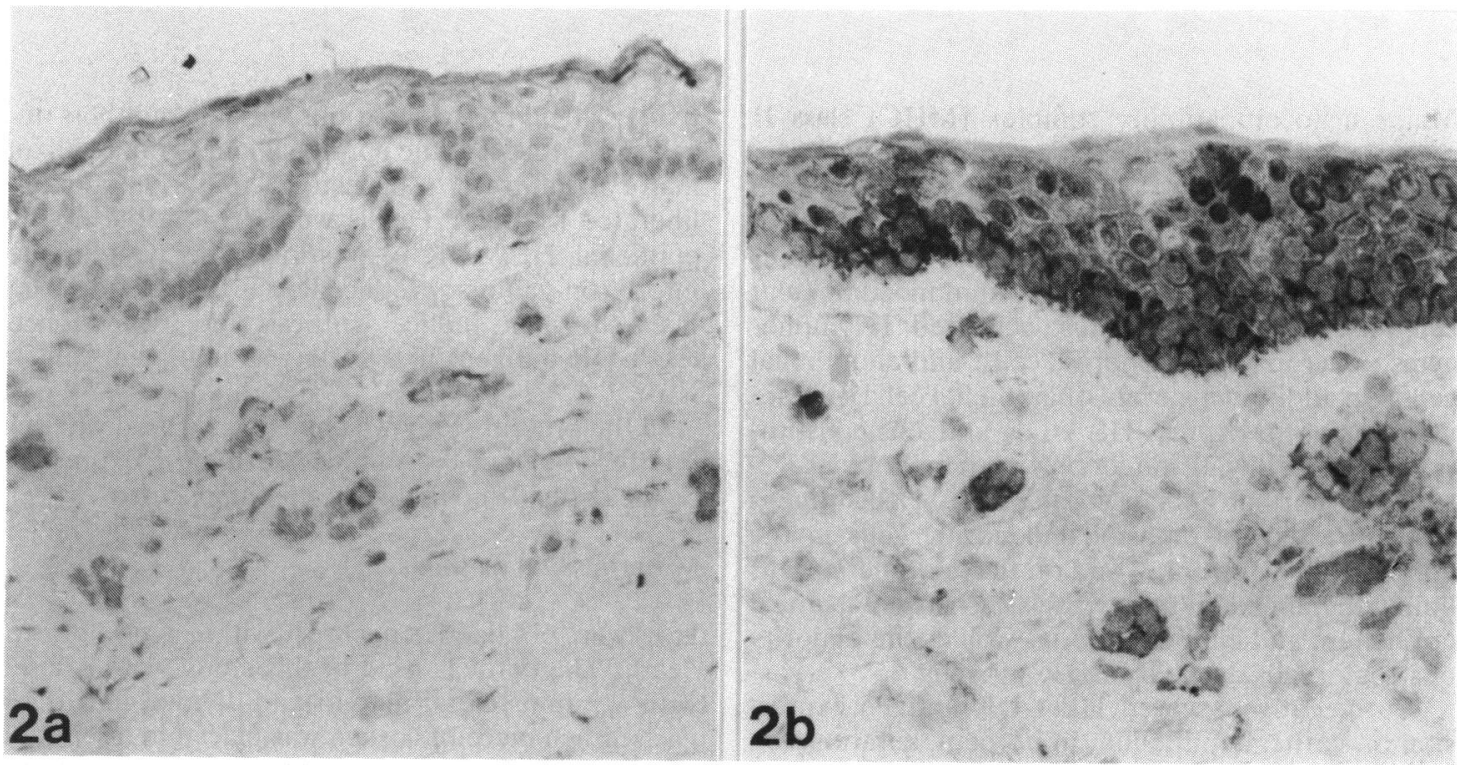

Fig. 2 Effect of interferon-gamma on HLA-DR expression by limbal epithelium. 2a. Weak reactivity is seen on the endothelium of some limbal blood vessels in the control specimen. $2 \mathrm{~b}$. Four days of incubation with $5 \mathrm{mg} / \mathrm{l}$ interferon-gamma reveals strong membranous and cytoplasmic HLA-DR expression by many epithelial cells as well as by the endothelium of most limbal blood vessels. (Three-step indirect immunoperoxidase method for TALIB5, slightly counterstained with Harris's haematoxylin; all figures $\times 260$.) 
Serial $5 \mu \mathrm{m}$ thick cryostat sections were stained with the three-step indirect immunoperoxidase method using monoclonal antibodies directed to MHC products. Monoclonal anti-HLA-ABC (Cappel Laboratories, Cochranville, PA) reacts with the constant part of HLA-ABC antigens. Monoclonal antibody TAL-1B5 was a generous gift from Dr W F Bodmer, Imperial Cancer Research Fund, London, and is directed against the monomorphic part of HLA-DR alpha chains, ${ }^{13}$ and monoclonal antibody L243 (Becton-Dickinson, Sunnyvale, CA), is directed against the monomorphic part of HLADR $\beta$ chains. ${ }^{14}$

\section{Results}

The control cornea that did not receive interferongamma expressed HLA-ABC antigens on epithelial cells, stromal cells, corneal endothelium, and on the endothelial cells lining the limbal blood vessels. HLA-DR expression, identified with monoclonal antibodies L243 and TAL-1B5, was restricted to occasional dendritic cells in the limbal epithelium and corneal stroma as well as to the endothelium of limbal blood vessels (Figs. 1a and 2A).

After four days of incubation with interferongamma the expression of HLA-ABC antigens was similar to that of the control cornea. However, monoclonal antibodies L243 and TAL-1B5 showed additional membranous and cytoplasmic HLA-DR expression by the corneal endothelium (Fig. 1b) as well as by variable numbers of epithelial cells, the most intense reactivity being found in the deepest epithelial layers (Fig. 2b). This additional HLA-DR expression was found with both concentrations of interferon-gamma employed.

\section{Discussion}

In this study we have shown that MHC class I products or HLA-ABC antigens are expressed on normal human corneal epithelium and stromal cells. These data are in accordance with earlier findings ${ }^{s-7}$ and indicate that epithelial and stromal cells can serve as target cells involved in allograft rejection. ${ }^{15}$ Moreover, the high density of HLA-ABC antigens on corneal epithelium provides an explanation for the decreased rejection rates when the epithelium is removed prior to transplantation, ${ }^{16}$ as well as for the prolonged graft survival, observed in MHC class I matched corneal transplants. ${ }^{17}$

Normal corneal endothelial cells have previously been found to lack MHC class I products. Our demonstration of HLA-ABC antigens on corneal endothelium can be explained by the short term culture of the tissue fragments, a procedure that has been shown in other studies to induce MHC class I products on corneal endothelium. ${ }^{18-20}$

We have also shown that MHC class II products or HLA-DR antigens are normally present on occasional dendritic cells in the limbal epithelium and on endothelial cells lining limbal blood vessels. After incubation with interferon-gamma, however, corneal epithelial and stromal cells were found to express HLA-DR antigens. This finding in vitro confirms and extends previous studies on cultured rabbit $^{21}$ and human epithelial and stromal cells. ${ }^{22-24}$ Moreover, the effect of low concentrations of interferon-gamma, namely, $5 \mathrm{mg} / \mathrm{l}$, provides good evidence that epithelial HLA-DR expression in various inflammatory conditions in vivo is indeed induced by interferon-gamma, released by activated $T$ cells.

Interferon-gamma also induced expression of HLA-DR antigens on corneal endothelium. This finding confirms previous studies employing cultured endothelial cells, and may indicate a potentiating role in the rejection of corneal allografts. ${ }^{15}$

HLA-DR expression by corneal epithelial and endothelial cells may render these cells susceptible to immunological attack by MHC class II restricted cytotoxic $\mathrm{T}$-cells $\mathrm{s}^{25}$ or may render them capable of acting as antigen presenting cells for T cells, thereby enhancing the immune response and possibly inducing an autoimmune response. ${ }^{26}$ Elucidation of the precise functional significance of corneal HLA-DR expression awaits further in-vitro studies.

This work was supported in part by the programme of scientific and clinical co-operation in the field of ophthalmic medicine and surgery between the University of Mansoura, Arab Republic of Egypt, and the Catholic University of Leuven, Leuven, Belgium.

\section{References}

1 Unanue ER. The regulatory role of macrophages in antigenic stimulation. Part 2: Symbiotic relationship between lymphocytes and macrophages. Adv Immunol 1981; 31: 1-136.

2 Endres RO, Kang AH. Induction of Ia antigens on nonlymphoid cells by lymphokines. Concepts Immunopathol 1988; 5: 57-79.

3 Gillette T, Chandler JW, Greiner JV. Langerhans cells of the ocular surface. Ophthalmology 1982; 89: 700-11.

4 Vantrappen L, Geboes K, Missotten L, Maudgal PC, Desmet VJ. Lymphocytes and Langerhans cells in normal human cornea. Invest Ophthalmol Vis Sci 1985; 26: 220-5.

5 Klareskog L, Forsum U, Tjernlund UM, Rask L, MalmnasTjernlund U. Expression of Ia antigen-like molecules on cells of the corneal epithelium. Invest Ophthalmol Vis Sci 1979; 18: 310-3.

6 Mayer DJ, Daar AS, Casey TA, Fabre JW. Localization of HLA-A,B,C and HLA-DR antigens in the human cornea: practical significance for grafting technique and HLA-typing. Transplant Proc 1983; 15: 126-9.

7 Treseler PA, Foulks GN, Sanfilippo F. The expression of HLA antigens by cells in the human cornea. Am J Ophthalmol 1984; 98: 763-72.

8 Abu El-Asrar AM, Geboes K, Missotten L, Emarah MH, Desmet VJ. Expression of MHC class II antigens and immunoglobulin $\mathrm{M}$ by the corneal epithelial cells in herpetic keratitis. Int Ophthalmol in press. 
9 Abu El-Asrar AM, van den Oord JJ, Geboes K. et al. Phenotypic characterization of inflammatory cells in phylctenular eye disease. Doc Ophthalmol in press.

10 Abu El-Asrar AM, van den Oord JJ, Geboes K. Missotten L. Emarah MH, Desmet VJ. Immunopathology of trachomatous conjunctivitis. Br J Ophthalmol 1989; 73: 276-82.

11 Basham TY, Nickoloff BJ. Merigan TC, Morhenn VB. Recombinant gamma interferon induces HLA-Dr expression on cultured human keratinocytes. J Invest Dermatol 1984: 83: 8890.

12 Sperling S. Human corneal endothelium in organ culture. The influence of temperature and medium of incubation. Acta Ophthalmol (Kbh) 1979: 57: 269-76.

13 Adams TE, Bodmer JG, Bodmer WF. Production and characterization of monoclonal antibodies recognizing the alphachain subunits of human la allo-antigens. Immunology 1983; 50: 613-24.

14 Lampson LA, Levy R. Two populations of Ia-like molecules on a human B cell line. J Immunol 1980; 125: 293-9.

15 Pepose JS, Gardner KM, Nestor MS, Foos RY, Pettit TH. Detection of HLA class I and II antigens in rejected human corneal allografts. Ophthalmology 1984: 92: 1480-4.

16 Tuberville AW, Foster CS. Wood TO. The effect of donor cornea epithelium removal on the incidence of allograft rejection reactions. Ophthalmology 1983: 90: 1351-6.

17 Foulks GH. Sanfilippo F. Beneficial effects of histocompatibility in high-risk corneal transplantation. Am J Ophthalmol 1982: 94: $622-9$

18 Newsome DA. Takasugi M, Kenyon KR, Stark WF, Opelz G.
Human corneal cells in vitro: morphology and histocompatibility (HL-A) antigens of pure cell populations. Invest Ophthalmol Vis Sci 1974; 13: 3223-32.

19 Fujikawa LS, Calvin RB, Bhan AK, Fuller TC, Foster CN. Expression of HLA-A/B/C and -DR locus antigens on epithelial, stromal, and endothelial cells of the human cornea. Cornea 1982: 1: $213-25$.

20 Whitsett CF. Stulting RD. The distribution of HLA antigens on human corneal tissue. Invest Ophthalmol Vis Sci 1984: 25: 519-24.

21 Young E, Stark WJ, Prendergast RA. Immunology of corneal allograft rejection: HLA-DR antigens on human corneal cells. Invest Ophthalmol Vis Sci 1985: 26: 571-4.

22 Donnelly JJ, Li W, Rockey JH, Prendergast RA. Induction of class II (Ia) alloantigen expression on corneal endothelium in vivo and in vitro. Invest Ophthalmol Vis Sci 1985: 26: 575-80.

23 Lynch MG, Peeler JS, Brown RH, Niederkorn JY. Expression of HLA class I and II antigens on cells of the human trabecular meshwork. Ophthalmology 1987: 94: 851-7.

24 Dreizen NG, Whitsett CF. Stulting RD. Modulation of HLA antigen expression on corneal epithelial and stromal cells. Invest Ophthalmol Vis Sci 1988; 29: 933-9.

25 Meuer SC, Hodgdon JC, Cooper DA. et al. . Human cytotoxic T cell clones directed at autologous virus transformed targets: further evidence for linkage of genetic restriction to $\mathrm{T} 4$ and $\mathrm{T} 8$ surface glycoproteins. J Immunol 1983; 131: 186-90.

26 Weetman AP. Aberrant class II antigen expression and autoimmunity. Concepts immunopathol 1988; 5: 21-43.

Accepted for publication 12 January 1989. 